\title{
Ctenodontina Enderlein, 1914 (Diptera, Asilidae, Asilinae): First Record for Brazil and Description of a New Species
}

\author{
Rodrigo Vieira \\ Programa de Pós-Graduação em Entomologia, Instituto Nacional de Pesquisas da Amazônia (INPA), CPEN, Campus II, \\ P.O. Box 478, 69011-970 Manaus, AM, Brazil
}

Correspondence should be addressed to Rodrigo Vieira, rodrigo08vieira@gmail.com

Received 18 November 2011; Accepted 11 December 2011

Academic Editor: C. L. Frank

Copyright ( $\odot 2012$ Rodrigo Vieira. This is an open access article distributed under the Creative Commons Attribution License, which permits unrestricted use, distribution, and reproduction in any medium, provided the original work is properly cited.

Ctenodontina Enderlein is reported for the first time in Brazil. A new species Ctenodontina nairae sp. nov. is described from the Amazonas state, Brazil. The habitus, wing, and structures of terminalia are described, and illustrated and a key to species is presented.

\section{Introduction}

Ctenodontina Enderlein is characterized by the epandrium narrowed apically (usually terminating in a finger-like lobe) and distinctly shorter than sternite $8[1,2]$. In the female, the ovipositor with apical ventral comb of spines, and with tergite 8 broadly expanded laterally, densely setose and cupped beneath, completely obscuring sternite 8 in profile $[1,2]$.

Ctenodontina is a Neotropical genus (Figure 1), comprising 4 species [3]: C. martini. Fisher [4]. This species was described by Fisher in Fisher and Hespenheide, 1992 [1] (Mexico and Guatemala), C. maya Carrera and d'Andretta [5] (Peru), C. mochica Lamas [6] (Peru), and C. pectinatipes Enderlein [7] (Colombia). Furthermore, Artigas and Papavero [8] illustrated a male hind femur of Ctenodontina sp. from Argentina, Jujuy, La Legua (Figure 2(e)), but they did not described the specimen. The same illustrations used by Artigas and Papavero [8] were used by Papavero et al. [9].

In this work a new species for Ctenodontina from Amazonas state, Brazil, is described and illustrated and a key for all species presently in Ctenodontina is provided.

\section{Material and Methods}

This study is based on the examination of specimens housed in the following Brazilian institutions: CZPB-Coleção Zoológica Prof. Paulo Bührnheim, Departamento de Biolo- gia, Universidade Federal do Amazonas, Manaus, Brazil, and Instituto Nacional de Pesquisas da Amazônia (INPA), Amazonas, Manaus, Brazil. Morphological terminology follows Cumming and Wood [10]. Detached wings were mounted on microslides in Canada Balsam. The microslides were glued on the edge of a piece of resistant paper and thereafter, attached at the same pin of the specimen. In this way, the piece is maintained detached next to the specimen. Dissected terminalia were treated in hot $\left(40^{\circ} \mathrm{C}\right) 10 \% \mathrm{KOH}$ for 8 hours, washed in water, posteriorly treated in $10 \%$ acetic acid and subsequently examined in excavated slides in glycerin. After examination and illustration, the detached parts were placed in microvials with glycerin and pinned with their respective specimens.

The label data is cited in full, with the original spellings, punctuations, and dates. Information presented within brackets is complementary data not included on the labels. Data for the same specimen but from different labels are separated by slashes (/). The map (Figure 1) was built with DIVA-GIS 7.4.0.

2.1. Key to Species to Ctenodontina Species Modified from Lamas [6]

(1) Male hind femur without swelling on the ventral surface of its apical 3/4, bearing a group of spine-like setae or subtuberculate spines (Figure $2(\mathrm{f}))-2$ 


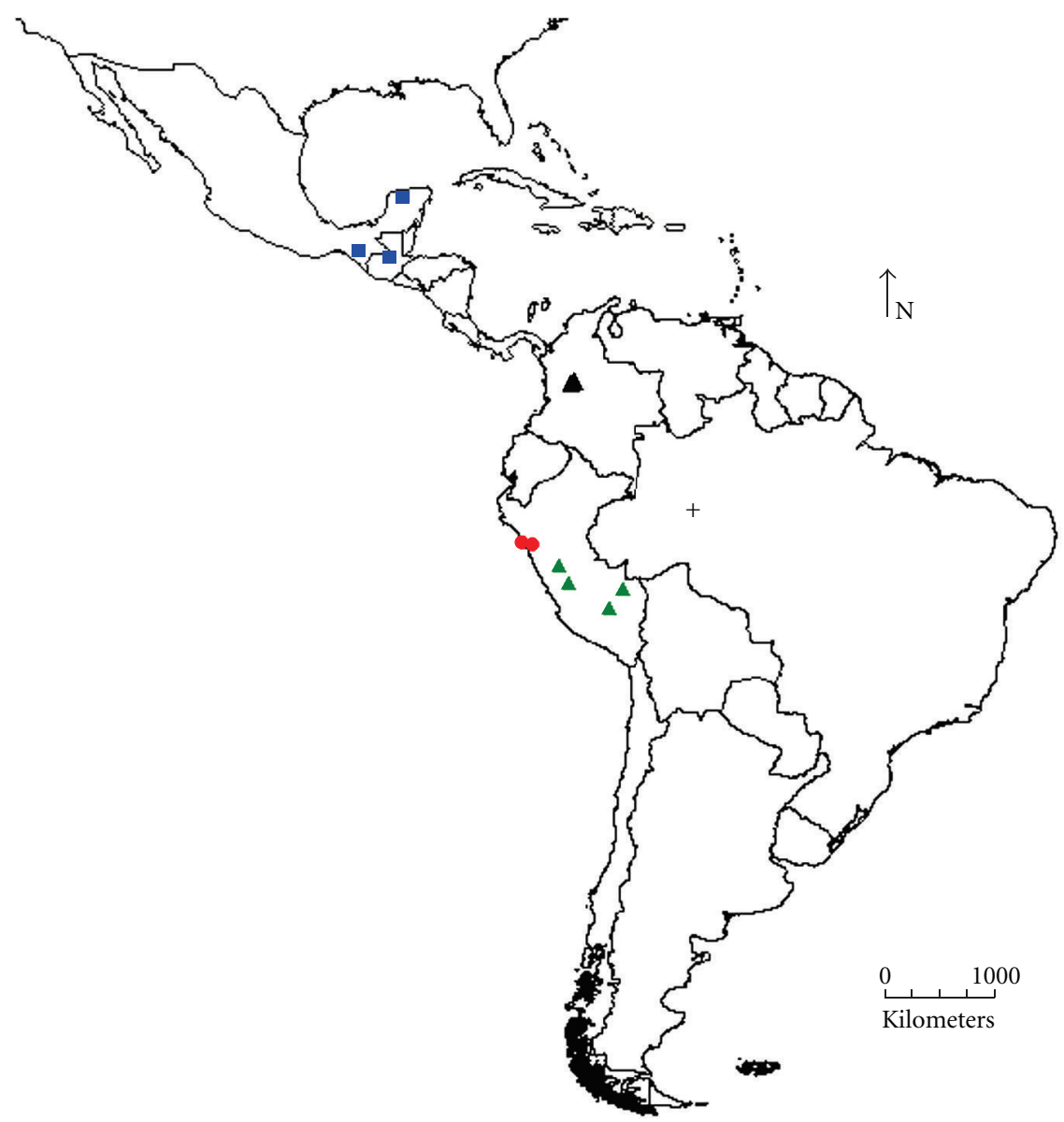

FIGURE 1: Map of distribution of Ctenodontina species (blue square Ctenodontina martini Fisher; black triangle Ctenodontina pectinatipes Enderlein; black cross Ctenodontina nairae Vieira sp. nov.; red circle, Ctenodontina mochica Lamas; green triangle, Ctenodontina maya Carrera and d'Andretta [5]).

Male hind femur with swelling on the ventral surface of its apical 3/4, bearing a group of spine-like setae or subtuberculate spines Figures 2(b) $-2(\mathrm{e}))-3$

(2) Epandrium wide basally with finger-like lobe placed dorsally. Apex of finger-like lobe rounded in lateral view Figure 2(a)) -C. martini Fisher in Fisher and Hespenheide [1].

Epandrium strongly excavated laterally with finger-like lobe placed ventrally. Apex of fingerlike lobe pointed in lateral view Figures 4(c)$4(\mathrm{~d}))-C$. nairae Vieira sp. nov.

(3) Femora completely light yellow brown; femoral swelling large and distinct Figures 2(c)-2(d) ) —4

Femora dorsally black; femoral swelling small (Figure 2(b)) -C. maya Carrera and d'Andretta [5].

(4) Mystax white with some black setae intermixed; femoral swelling on apical half, comb-like, with long, stout teeth Figure $2(\mathrm{~d}))-C$. pectinatipes Enderlein [7].

Mystax entirely white; femoral swelling on apical fourth, sack-like, with short, slender teeth (Figure 2(c))—C. mochica Lamas [6].

\subsection{Description}

Ctenodontina nairae Vieira sp. nov. (Figures 2(f), 3(a)-3(b) and $4(a)-4(j))$.

2.2.1. Description Male Holotype. Head. Antennae black; orbital setae black; vertex black; face black with golden tomentose; mystacal macrosetae yellow, except black on lateral margin and portion superior of facial gibbosity; frons black sparsely yellow tomentose; occiput gray tomentose; occipital setae whitish; 5-6 black postocular macrosetae; palpus black with black setae, yellowish setae only at base; apical setae of palpus longer than others; proboscis black with yellowish ventral setae; labial setae yellowish.

Thorax (Figure 3(a)). Antepronotum and postpronotum black, brown tomentose; mesonotum black with golden 


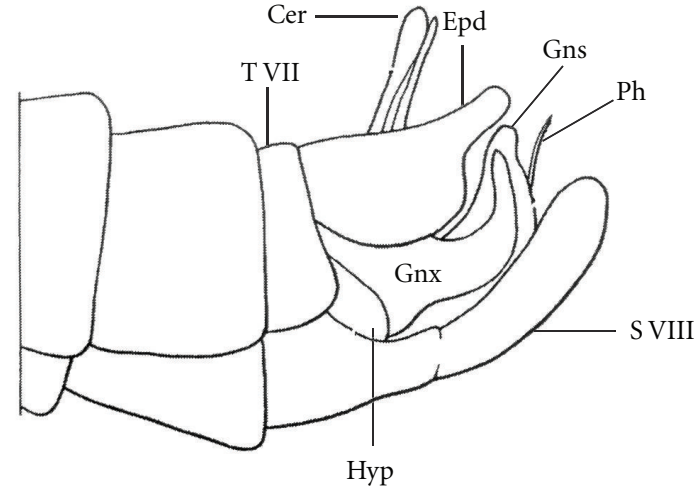

(a)

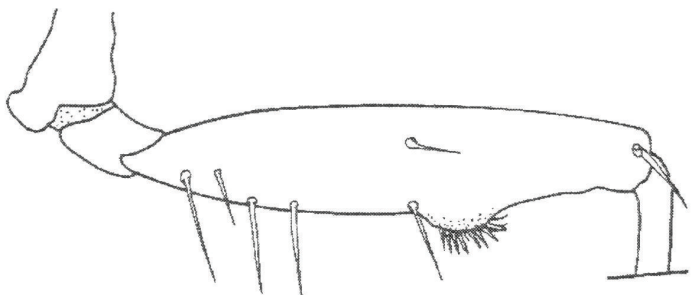

(b)

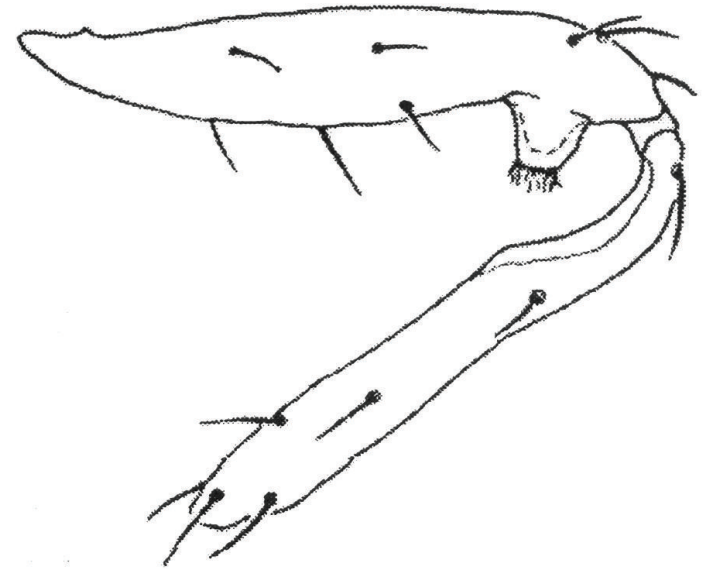

(c)

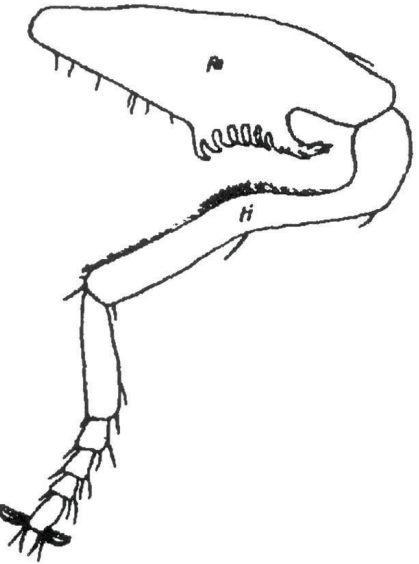

(d)

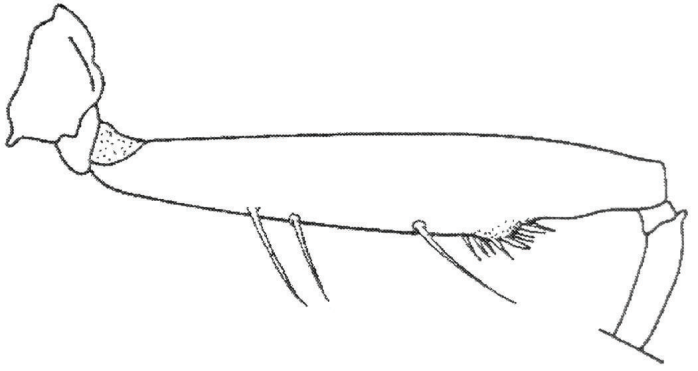

(e)

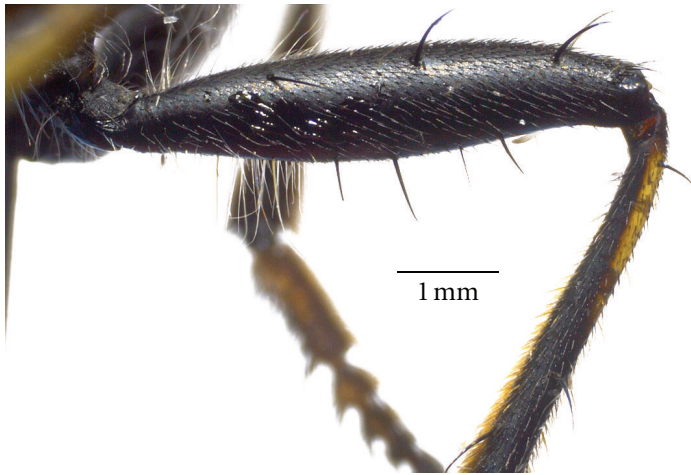

(f)

FIGURE 2: was built with (a) male terminalia in lateral view of Ctenodontina martini Fisher (modified from Fisher [8]); (b) male hind femur of Ctenodontina maya Carrera and d'Andretta (modified from Papavero et al. [9]); (c) male hind femur of Ctenodontina mochica Lamas (modified from Lamas [6]); (d) male hind femur of Ctenodontina pectinatipes Enderlein (modified from Enderlein [7]); (e) male hind femur of Ctenodontina sp. (modified from Papavero et al. [9]); (f) male hind femur of Ctenodontina nairae Vieira sp. nov.

tomentose border in dorsal view; posthumeral and lateroscutal spots brown tomentose and prescutellar spot grayish tomentose; scutellum black, gray tomentose; pleuron black, gray tomentose. Chaetotaxy: 2 notopleural macrosetae; 2 supra-alar macrosetae; 1 postalar macroseta; 5-6 pairs of postsutural dorsocentral macrosetae; no apical scutellar macrosetae; no anatergal seta; discal scutellar setae black; setae on posterior meron + metanepisternum whitish; katatergal setae whitish.

Wing (Figure 3(b)). Brown infuscated, mainly at distal half; no costal dilation; $\mathrm{R}_{4}$ and $\mathrm{R}_{5}$ bifurcation placed beyond discal cell apex; crossvein $\mathrm{r}-\mathrm{m}$ situated beyond middle of discal cell; microtrichia on posterior margin arranged in a single plane; halter pale yellow mixed with black. 


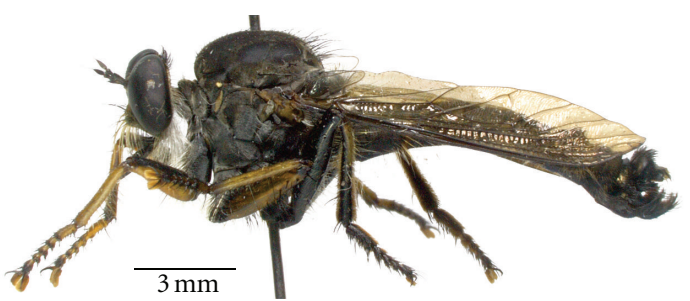

(a)

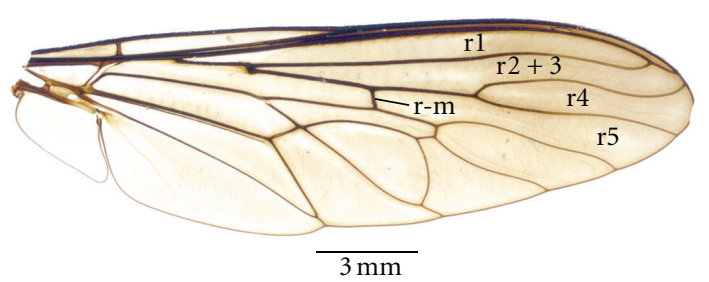

(b)

FIgure 3: Ctenodontina nairae Vieira sp. nov. (a) male lateral habitus; (b) wing.

Legs (Figures 2(f) and 3(a)). Fore and midfemora dorsally and anteriorly black, ventrally and posteroventrally yellowish, except black narrow apex of mid femora posteroventrally; hind femora wholly black, without swelling (Figure 2(f)); fore tibia dorsally, ventrally and posteriorly yellowish, anteriorly with brown longitudinal stripe with brown, short close spaced, spiniform setae and a yellow longitudinal stripe. Mid tibiae dorsally, posteriorly and ventrally yellow, anteriorly with yellow longitudinal stripe and black stripe. Hind tibiae black, except yellow basal half dorsally. Fore and midtarsomeres yellow, except black apex of tarsomeres 1-4 and black apical half of tarsomere 5. Hind tarsomere black mixed with brown. Chaetotaxy: hind trochanter with yellow setae; fore femora with yellow and black setae ventrally; middle femora with 5 black anterior macrosetae, 6 black macrosetae and 1 yellow seta posteriorly, 33 black macrosetae ventrally; hind femora with 3 black macrosetae anterior, 3 black macrosetae anteroventrally; fore tibiae with 5 black setae dorsally, middle tibiae with 2 black macrosetae anteroventrally; hind tibia with 1 black preapical macroseta anteroventrally; all macrosetae and setae of tarsomeres black.

Abdomen (Figure 3(a)). Black. Tergites and sternites II-V brown at apex. Tergites II-III with yellow lateral macrosetae. Sternite VIII elongate with a projection of truncated apex, longer than terminalia in lateral view (Figures 4(a)-4(e)). Sternite VIII predominantly black with some brown parts. Sternite VIII densely black and with brown setae on lateral margin and at apex of projection (Figures 4(a)-4(e)).

Terminalia (Figures 4(b)-4(j)). Black (Figure 4(c)). Epandrium strongly excavated laterally with finger-like lobe placed ventrally (Figures 4(c)-4(d)); apex of finger-like lobe pointed in lateral view (Figures 4(c)-4(d)) and slightly bifid in frontal view; epandrium with 4 long macrosetae on inferior margin and long setae on superior margin in lateral view (Figures $4(\mathrm{~b})$ and $4(\mathrm{~d})-4(\mathrm{f})$ ); gonocoxite triangular (Figures 4(f) and 4(h)) with apex digitiform (Figure 4(h)); inferior margin preapically of gonocoxite with some black minute setae spiniform, close spaced, in lateral view (Figure 4(h)); gonostylus curved, situated proximally of gonocoxite (Figures $4(\mathrm{f})$ and $4(\mathrm{~h})-4(\mathrm{i})$ ), with apex truncated and numerous spiniform setae laterally (Figure 4(i)); hypandrium reduced and extremely narrow medially (Figure 4(f)); hypandrium with long setae at apex of lateral margins (Figure 4(f)); subepandrial sclerite with a kell medially and with 2 macrosetae distally (Figure $4(\mathrm{~g})$ ); subepandrial sclerite with two lobes laterally covered by spiral shaped setae (Figure $4(\mathrm{~g})$ ); each cercus with 3 macrosetae at apex (Figure 4(g)); phallus with 2 prongs (Figure $4(\mathrm{j})$ ); ejaculatory apodeme wide in lateral view (Figure $4(\mathrm{j}))$.

\subsubsection{Size. Body length $21 \mathrm{~mm}$.}

2.2.3. Holotype Condition. 1 left notopleural macroseta lost. Detached wing mounted on microslides, terminalia placed in microvials with glycerin and pinned along with the specimen.

2.2.4. Variation. Male: 7-9 pairs of postsutural dorsocentral macrosetae and 1 pair of presutural; 7 black macrosetae on left mid femur; right hind femur with 4 black anterior macrosetae, 2 black anteroventral macrosetae; body length $19.6 \mathrm{~mm}$.

\subsubsection{Female. Unknown.}

2.2.6. Etymology. The species name is dedicated to Dr. Nair Aguiar, a professor from Universidade Federal do Amazonas.

\subsubsection{Geographical Records. Brazil: Amazonas state (Figure 1).}

2.2.8. Comments. C. nairae Vieira sp. nov. differ from other Ctenodontina species by the characters presented in the identification key. Furthermore, C. nairae Vieira sp. nov. can be separated from Ctenodontina sp. (Argentina) because it do not possess a spinous swelling ventrally on male hind femora (Figures 2(e)-2(f)). According to Fisher [4], various authors mentioned a spinous swelling ventrally on male hind femora (Figures 2(b)-2(e)) as the main diagnostic characteristic of Ctenodontina. Fisher [4] comments that this is an unreliable generic character-this condition not present in all species and Ctenodontina is better defined by its very distinctive male and female terminalia.

2.2.9. Type Material Examined. Holotype: Brasil, Amazonas, Coari, rio Urucu, Ig.[arapé] Marta- $3,4^{\circ} 50^{\prime} 0,73^{\prime \prime} \mathrm{S}$, $65^{\circ} 02^{\prime} 37^{\prime \prime} \mathrm{W}, 14-25$.viii.1993, P. F. Bührnheim et al. col./ Armadilha de Malaise/Holótipo Ctenodontina nairae Vieira ( $\left.0^{\top} \mathrm{CZPB}\right)$. 


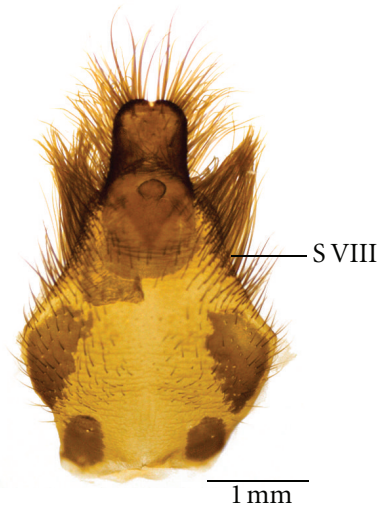

(a)

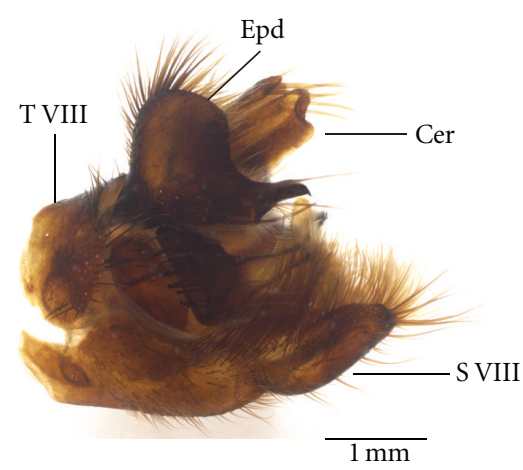

(d)

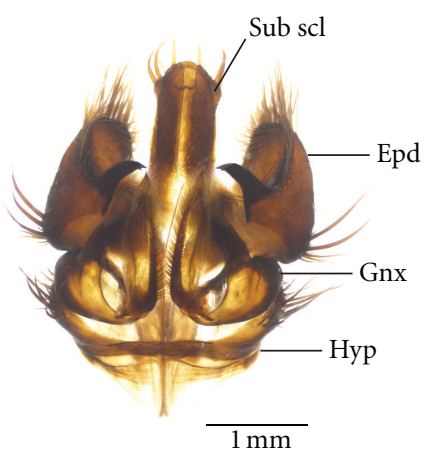

(f)

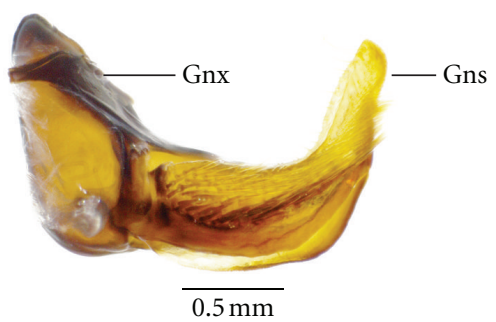

(i)

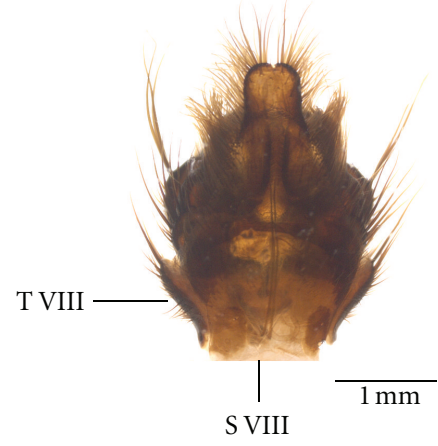

(b)

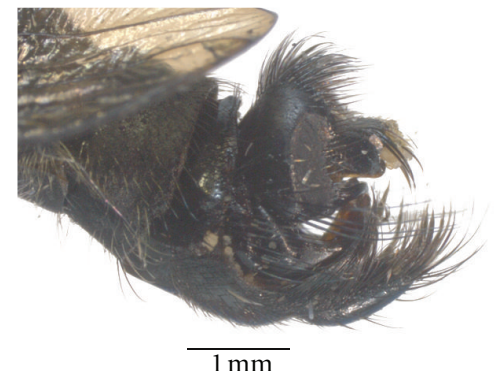

(c)

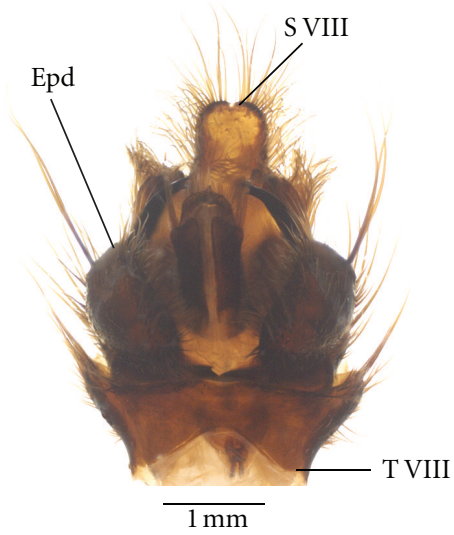

(e)

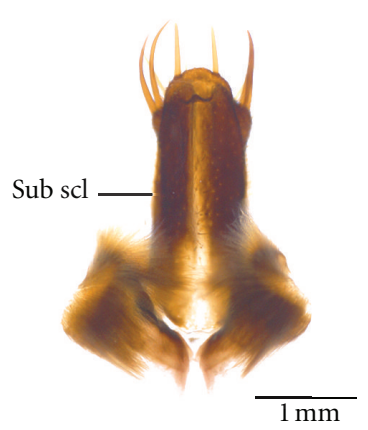

(g)

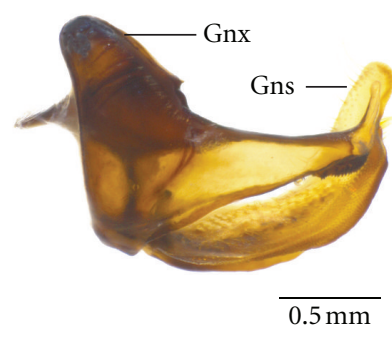

(h)

FIGURE 4: Ctenodontina nairae Vieira sp. nov. (a) male sternite VIII; (b) male terminalia in ventral view; (c) male terminalia in lateral view; (d) male terminalia in lateral view treated in hot $10 \% \mathrm{KOH}$; (e) male terminalia in dorsal view; (f) male terminalia in ventral view (without sternite VIII); (g) subepandrial sclerite; (h) gonocoxito and gonostylus; (i) gonostylus and inner margin of gonocoxite; (j) phallus and ejaculatory apodeme in lateral view. 
Paratypes: Brasil, Amazonas, Coari, rio Urucu, Angelim, $5^{\circ} 3^{\prime} 33^{\prime \prime}$ S, 65 $14^{\prime} 48^{\prime \prime} \mathrm{W}$, 23.xi-02.xii.1992, P. F. Bührnheim and N.O. Aguiar/Armadilha de Shannon/Paratype Ctenodontina nairae Vieira ( $\sigma^{7}$ INPA).

\section{Abbreviations}

Cer: Cercus

Ej Apod: Ejaculatory apodeme

Epd: $\quad$ Epandrium

Gnx: Gonocoxite

Gst: Gonostylus

Hyp: Hypandrium

Ph: Phallus

Sub scl: Subepandrial sclerite

S VIII: Sternite VIII

T VIII: Tergite VIII.

\section{Acknowledgments}

Thanks are due to Fabio Godoi (CZPB) and Dr. Nair Aguiar (CZPB) for the loan of the specimens, to Dr. José Albertino Rafael (INPA) for the critical review of the paper, to Fundação de Amparo à Pesquisa do Estado do Amazonas (FAPEAM) and to CNPq for the financial support.

\section{References}

[1] E. M. Fisher and H. A. Hespenheide, "Taxonomy and biology of central American robber flies with an illustrated key to the genera (Diptera, Asilidae)," in Insects of Panama and MesoAmerica, D. Q. Arias and A. Aiello, Eds., pp. 611-632, Oxford University Press, Oxford, UK, 1992.

[2] E. Fisher, "Asilidae (Robber flies, Assassin flies, Moscas Cazadoras, Moscas Ladronas)," in Manual of Central American Diptera, B. V. Brown, A. Borkent, J. M. Cumming, D. M. Wood, N. E. Woodley, and M. A. Zumbado, Eds., vol. 1, Chapter 45, pp. 585-632, National Research Council Research Press, Ottawa, Canada, 2009.

[3] N. Papavero, "Catalogue of Neotropical Diptera. Asilidae," Neotropical Diptera, vol. 17, pp. 1-179, 2009.

[4] E. M. Fisher, "A preliminary list of the robberflies (Diptera: Asilidae) of the Tambopata Reserved Zone, Madre de Dios, Peru," Revista peruana de Entomologia, vol. 27, pp. 25-36, 1985.

[5] M. Carrera and M. A. V. d'Andretta, "Asilideos do Peru (Diptera)," Papéis avulsos do Departamento de Zoologia. Secretaria da Agricultura, vol. 11, no. 9, pp. 63-78, 1953.

[6] G. Lamas, "Some comments on the genus Ctenodontina Enderlein (Diptera, Asilidae), with the description of a new species from coastal Peru," Papéis avulsos de Zoologia, vol. 26, no. 23, pp. 275-280, 1973.

[7] G. Enderlein, "Dipterologische Studien. XI. Zur Kenntnis tropischer Asiliden," Zoologischer Anzeiger, vol. 44, no. 6, pp. 241-263, 1914.

[8] J. N. Artigas and N. Papavero, "The American genera of Asilidae (Diptera): keys for identification with an atlas of female spermathecae and other morphological details. IX.10. Subfamily Asilinae Leach-Lecania-group, with a catalogue of the Neotropical species," Theoria, vol. 4, pp. 33-56, 1995.
[9] N. Papavero, C. J. N. Artigas, and C. J. E. Lamas, "Manual of Neotropical Diptera. Asilidae," Neotropical Diptera, vol. 18, pp. 1-322, 2009.

[10] J. M. Cumming and D. M. Wood, "Adult morphology and terminology," in Manual of Central American Diptera, B. V. Brown, A. Borkent, J. M. Cumming, D. M. Wood, N.E. Woodley, and M. A. Zumbado, Eds., vol. 1, Chapter 2, pp. 9-50, National Research Council Research Press, Ottawa, Canada, 2009. 

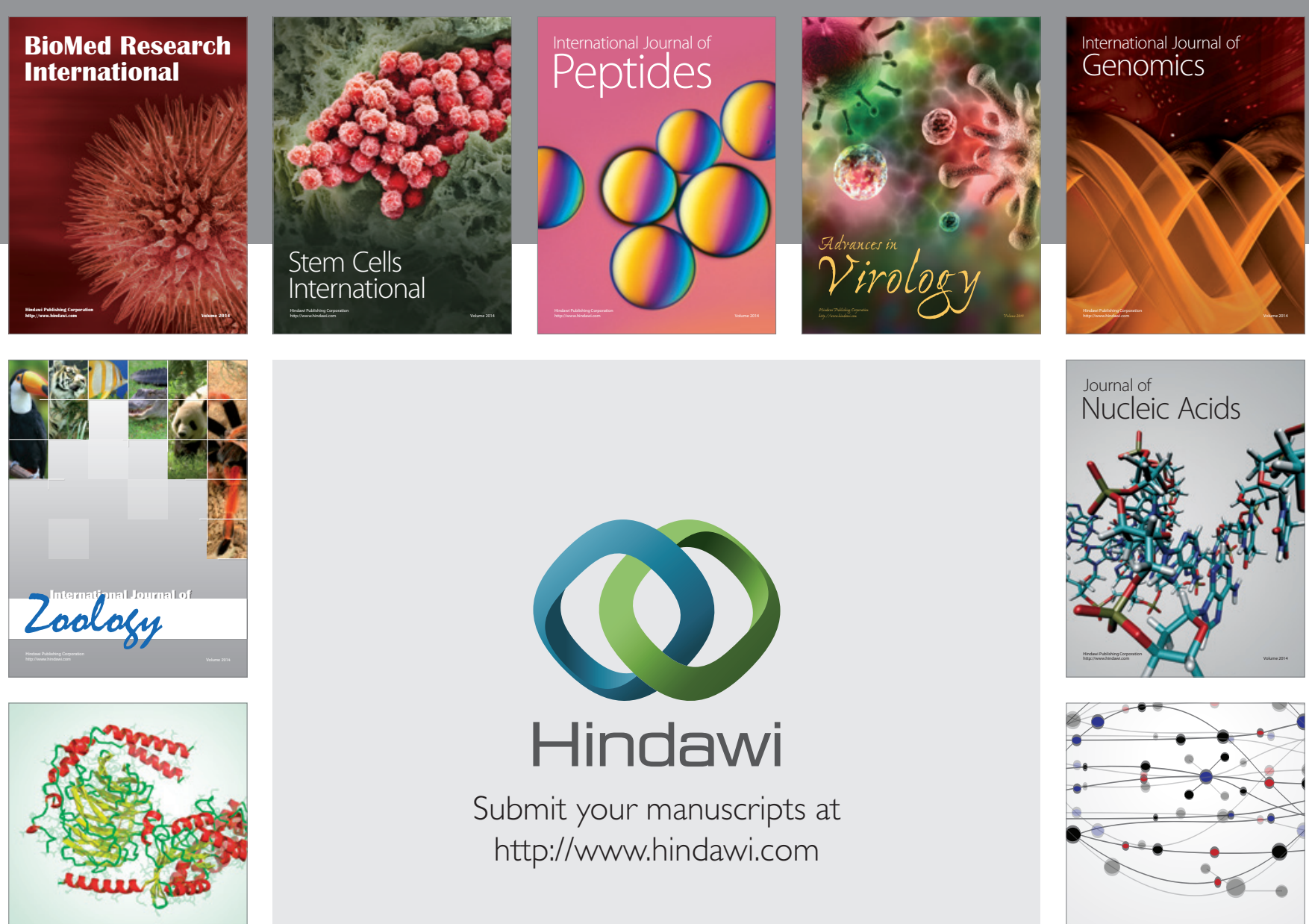

Submit your manuscripts at

http://www.hindawi.com

Signal ${ }^{\text {Jumal }}$ Transduction
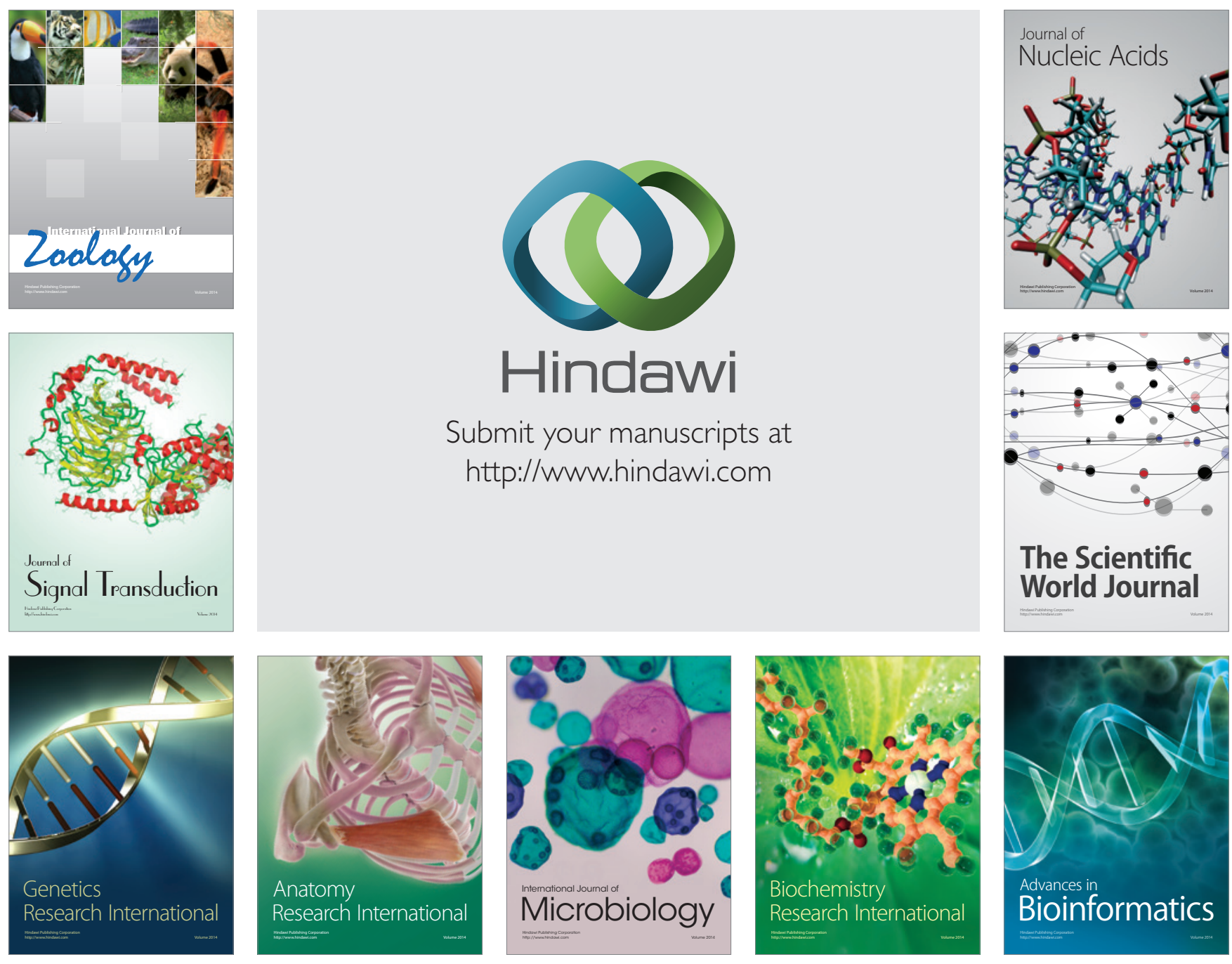

The Scientific World Journal
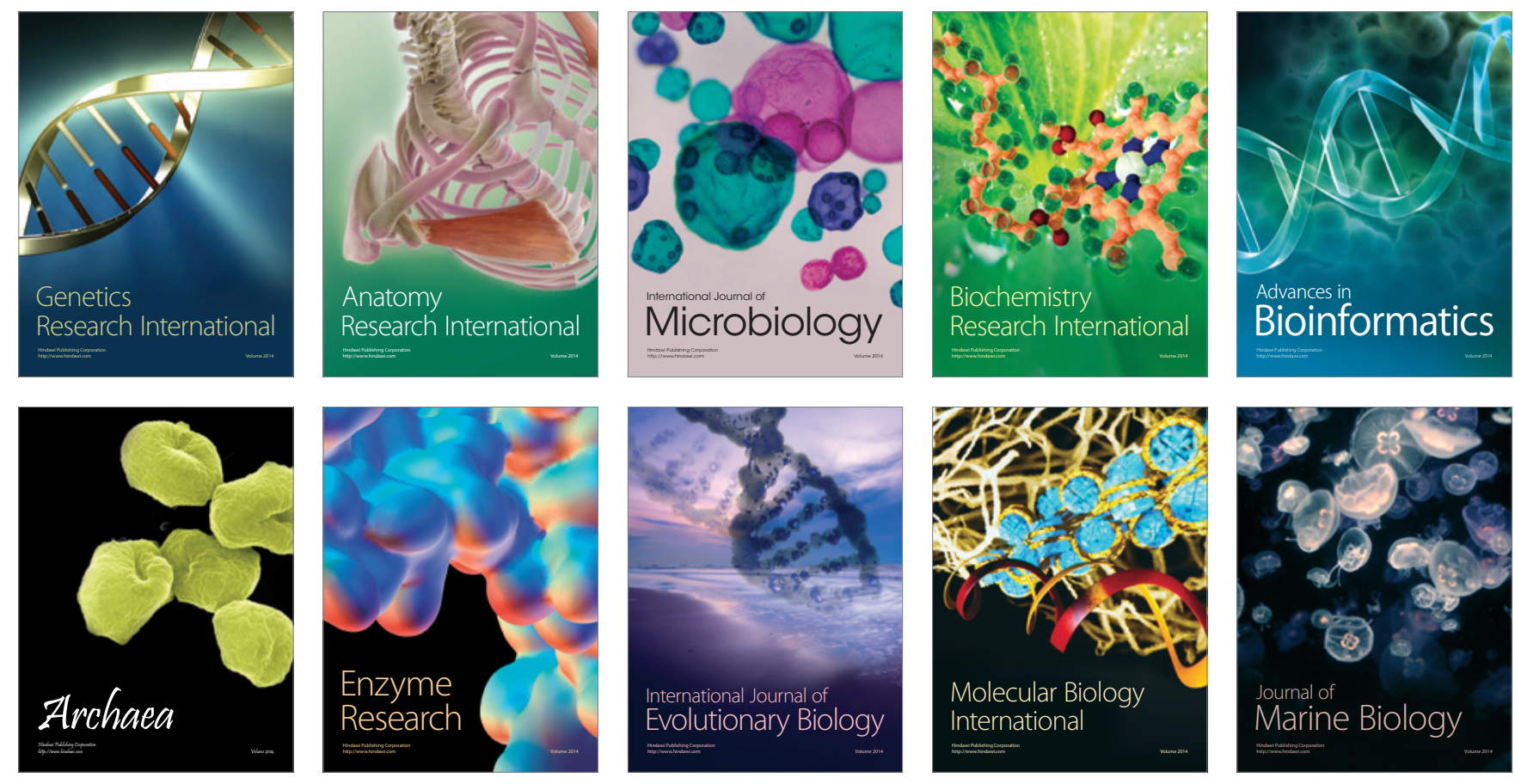